\title{
ACP5 Gene Product
}

National Cancer Institute

\section{Source}

National Cancer Institute. ACP5 Gene Product. NCI Thesaurus. Code C99183.

A protein encoded by the ACP5 gene. 